\title{
Mens Rea and the Right to Trial by Jury
}

This Comment argues that the sixth amendment requires a jury finding of moral blameworthiness as a prerequisite to criminal punishment. The author examines the meaning of the mens rea requirement at the time that the sixth amendment was adopted. She argues that the mens rea element present when the sixth amendment was ratified connoted a requirement that the defendant be morally blameworthy. The presence of mens rea was a jury question and thus, the author concludes, it was a necessary condition to criminal punishment. The Comment then explores the historical development of strict criminal liability and related developments in criminal law. The author suggests that the Supreme Court has erred in deferring broadly to the legislature's authority to create crimes while ignoring the important constitutional limit on government power intended by the mens rea requirement. The Comment concludes that a sixth amendment requirement that a jury find moral guilt in all criminal cases would both allow the Court properly to defer to legislative enactments and protect the morally innocent from unjust punishment.

\section{INTRODUCTION}

There is broad and longstanding societal consensus that there should be no criminal punishment without inoral blameworthiness. ${ }^{1}$ Nevertheless, strict liability crimes have flourished, especially in the past fifty years. Even when a mental state is included as an eleinent of a crime, the inental element no longer necessarily connotes moral blame. The United States Supreine Court has placed only narrow due process limits on the ability of legislatures to eliminate the need to find mens rea, or guilty mind, before imposing criminal sanctions. The Court, it seems,

1. See, e.g., $1 \mathrm{~J}$. Bishop, Commentaries on the Criminal Law \$227, at 260 (2d ed. 1858) ("[N]either in philosophical speculation, nor in religious or moral sentiment, would any people in any age allow, that a man should be decmed guilty unless his mind were so."); $4 \mathrm{~W}$. BLACKSTONE, COMMENTARIEs *21 ("[A]n unwarrantable act without a vicious will is no crime at all."); E. COKE, THE THIRd Part of THE INSTITUTes of THE LAWS of ENGLAND *6, *107 ("Actus non facit reum, nisi mens sit rea."); H. PAcker, The Limits of the Criminal SANCtion 16 (1968) ("[A] finding of moral responsibility is a necessary although not a sufficient condition for determining criminal guilt and meting out punishment for it."); Hart, The Aims of the Criminal Law, 23 LAw \& CONTEMP. ProBs. 401, 405 (1958) (Crime "is conduct which, if duly shown to have taken place, will incur a formal and solemn pronouncement of the moral condemnation of the community"); Packer, Mens Rea and the Supreme Court, 1962 Sup. CT. REv. 107, 148 ("So long as [the criminal] sanction is resorted to, moral blameworthiness should be the indispensable condition precedent to its application."); Note, Criminal Liability Without Fault: A Philosophical Perspective, 75 CoLUM. L. REv. 1517, 1517 (1975) ("[T]he . . elimination of moral responsibility as an element of certain criminal offenses has been received with widespread judicial disparagement."). 
is reluctant to substitute its judgment of crimmal guilt for the judgment of the legislature.

The Court is unwilling to require a finding of mens rea as a prerequisite to criminal punishment because it does not distinguish between the issues raised by eliminating moral blameworthiness as a required element of all crimes and those raised by eliminating particular mental states from the defiuritions of particular crimes. While use of increasingly particularized mental states and elmination of mental states may be rightly within the legislative prerogative, this Comment argues that the criminal defendant nevertheless has a fundamental constitutional right to have a jury of her peers decide if she is morally blameworthy.

Part I of this Comment discusses the historical basis for a constitutional mens rea requirement. Part II briefly describes the historical forces behind strict criminal liability, and discusses how these forces have affected the development of federal doctrine concerning mens rea. Part III examines why past attacks on strict criminal liability have failed. Part IV argues that in addition to the more abstract historical, jurisprudential, and philosophical reasons for preserving the traditional mens rea requirement, rooting such a requirement in the sixth amendinent eliminates many objections and concerns raised by previous atteinpts to ground mens rea elsewhere in the constitutional text. This Coinment concludes that the creation of a constitutional right to a jury finding of moral guilt is necessary to preserve the essence of the right to trial by jury.

\section{I}

Historical Meaning of THE TERMS

\section{A. The Meaning of Mens Rea to the Framers}

In 1932, F.B. Sayre wrote, "It is hopeless to find any general universal concept of mens rea ...." He traced the emergence and development of this eleinent of crime and concluded that the term mens rea "has no fixed continuing meaning."3 Instead, conceptions of mens rea changed as the theories and purposes of criminal justice changed. Thus, when the object of criminal law was to supplant the blood feud, ${ }^{4}$ the mens rea requirement served to punish actions that were likely to provoke retaliation. ${ }^{5}$ By the end of the twelfth century, when the growing influence of canon law changed the purpose of criminal law to punish-

2. Sayre, Mens Rea, 45 HARv. L. Rev. 974, 1020 (1932).

3. Id. at 1016.

4. A blood feud is defined as "[a]venging the killing of kin on the person who killed him, or on his family." BLACK's LAw DictionaRY 157 (5th ed. 1979).

5. Sayre, supra note 2, at 1016. Through the twelfth century, criminal law focused on the provocative nature of the act in question. Id. at 975-82. 
ment of wrongdoing, mens rea came to mean "a mind bent on evil-doing in the sense of moral wrong." Sayre believed that, in modern times, the objectives of criminal law gradually had shifted from punishment of moral wrongdoing to the protection of social and public interests. ${ }^{7}$ Although the mental element necessary for conviction was not completely divorced from ethical concepts, a shift in emphasis had occurred and the definition of mens rea for various crimes became increasingly technical to reflect the shift. Thus, arson's malice element is no longer "the intent to injure in a feud-provoking way ... [but instead] a narrow specific intent to burn a house occupied as a dwelling; the motive may be entirely free froin malevolence or desire to injure."8

As part of this trend toward using criminal law as a means of effecting social policies, rather tlian as a ineans of punishing moral wrongdoing, courts began to impose an objective standard im criminal law that ignored the actor's state of mind.9 Also, though a mental eleinent usually still was required to convict, the elenent no longer required that the criminal have a general evil underlying motive, but only a specific form of intent. ${ }^{10}$

Sayre approved, albeit with reservations, the shifting conceptions of "guilty unind," seeing them as instances of the "[c]onstant and neverending differentiation of apparently similar but essentially dissimilar situations ... inherent in the growth of law." " But while he did a superb job of explaining how the courts were redefining the mental element, Sayre did not atteinpt to examine critically whether the courts' slifting conceptions iniplicated any values of constitutional importance. In particular, Sayre failed to consider these new developments in light of the conception of mens rea when the Constitution was adopted.

Although "the history of the elucidation of the mens rea concept is a dispiriting record of legislative, judicial, and scholarly imprecision,"12 theories of criminal responsibility nonetlieless have centered around just this elusive concept throughout American history. That there are no

6. Id. at $982-83,1016-17$.

7. "To the extent that this objective prevails, the mental element requisite for criminality, if not altogether dispensed with, is coming to mean, not so much a mind bent on evil-doing as an intent to do that which unduly endangers social or public interests." Id. at 1017 (footnotes omitted).

8. Id.

9. Id. at 1019; see also O. Holmes, The COMmon LAw 50 (1923) ("[T]he tests of liability are external, and independent of the degree of evil in the particular person's motives or intentions.").

10. Sayre, supra note 2, at 1019.

11. Id. at 1020 . Sayre approved of the shift in emphasis "[i]nsofar as the more precise defining of the mental element required for each felony followed this constant effort to differentiate right from wrong." Id. His concern was that "[e]ffective criminal administration may be greatly hampered by undue particularization of closely allied crimes." Id.

12. Dubin, Mens Rea Reconsidered: A Plea for a Due Process Concept of Criminal Responsibility, 18 StaN. L. Rev. 322, 351 (1966). 
simple formulations does not mean that there has never been a unifying idea. In the late eighteenth century there was a unifying idea: moral blameworthiness. ${ }^{13}$

The Constitution does not discuss principles of criminal responsibility, ${ }^{14}$ and the Framers left us no written statenients about mens rea. However, this vacuum may exist at least partly because there was a great deal of consensus about the topic. In fact, the writings of the eighteenth century's foremost crimmal law scholars-Hawkins, Foster, and Blackstone-demonstrate that the "connection between crime and moral guilt [was] enshrined in the common law."15 As Hawkins stated: "The Guilt of offending agamst any Law whatsoever, necessarily supposing a wilful Disobedience, can never justly be imputed to those, who are either uncapable of understanding it, or of conforming themselves to it . . ."16 Foster and Blackstone likewise recognized that there sliould be no judgment of criminality without a finding of moral culpability. ${ }^{17}$

Thus, according to the experts of the period, the doctrine that a defendant was not criminally liable if sle was free from moral fault was universally recognized and accepted during the latter half of the eighteenth century. Strict liability crimes did not exist. ${ }^{18}$

13. See, e.g., P. BRETt, AN INQU1RY INTo CRIMiNAl Gullt 37-41 (1963) (discussing eighteenth century commentators on mens rea and concluding that the thread that held together the body of decisional law was the concept of moral fault or blameworthiness).

14. See Dubin, supra note 12 , at 367.

15. P. BRETT, supra note 13 , at 38 .

16. 1 W. Hawkins, Pleas of the Crown 1 (n.p. 1716), quoted in P. BretT, supra note 13, at 39 .

17. Though the jury may, and have been formerly directed in the cases of infancy and insanity to find the special matter, whereupon the court is to give judgment of acquittal, yet, under the direction of the court, they may find a general verdict of acquittal without this circuity.

This rule is founded in sound reason and substantial justice; for undoubtedly crimen non contrahitur nisi voluntas nocendi intercedat.

M. Foster, Crown LAw 279 (3d ed. 1809), guoted in P. BRETT, supra note 13, at 39.

Indeed, to make a complete crime cognizable by human laws, there must be both a will and an act. For though, in foro conscientiae, a fixed design or will to do an unlawful act, is almost as heinous as the commission of it, yet, as no temporal tribunal can search the heart, or fathom the intentions of the mind, otherwise than as they are demonstrated by outward actions, it therefore cannot punish for what it cannot know. . . . And, as a vicious will without a vicious act is no civil crime, so, on the other hand, an unwarrantable act without $a$ vicious will is no crime at all.

4 W. Blackstone, Commentaries *20-21, quoted in P. BRETT, supra note 13, at 40 (second emphasis added).

18. The principle of blameworthiness expressed by these writers is derived not from statutory law but from case law, and much of the case law "evolved by way of implied exceptions (that is, implied by the judges) to apparently express and precise statutory commands." P. BRETT, supra note 13 , at 40 . 


\section{B. The Right to Jury Trial}

Nowhere is trial by jury more important than in the United States, ${ }^{19}$ and no other country confers a right to jury trial in as many proceedings. ${ }^{20}$ The use of juries in American practice began during the colonial period, when colonists transported the Enghish jury system, which already had evolved to include the right to an impartial jury of one's peers. ${ }^{21}$ The American systen, however, varied in several ways from its British counterpart during the colonial period and has continued to evolve and change over the centuries. ${ }^{22}$

The jury attained special political importance in America for a number of reasons. While the American colonists felt an allegiance to their English king and to the customs, pohitical institutions, and laws of the mother country, "the colonists had to cope with the special problems of an expanding society with uncertain frontiers."23 There were few judges trained in law, and jurors were presuined to be as expert at deciding law as the lay judges. Also, the Crown tended to appoint avaricious governors and admimistrators who were insensitive to the colonists' needs. Rather than rely on an inadequate corps of judges, the colonists began to develop their own views on law and justice. These views elevated the role of the jury in the legal system: "the jury of peers in itself became a ready-made vehicle for implententing revolutionary ideas and principles . . .."24

This political significance of the jury was given voice in the trial of John Peter Zenger for seditious libel in 1735. At the time, the jury in a libel case decided only whether the defendant had published the newspaper, while tlie judge decided whether the articles printed in it were libelous. Zenger's attorney, Andrew Hamilton, argued that since the state existed to protect tlie liberties of its citizens, citizens need not obey orders of state officials that would curtail those liberties. Hamilton articulated "developing American ideas about the relationship between state and citizen-and the place of the jury in this new schene of thinking"25: "Juryinen are to see with their own eyes, to liear with their own ears, and to make use of their own consciences and understandings, in

19. See V. HANS \& N. VIDMAR, JUDGING THE JURY 31 (1986) ("Estimates are that $80 \%$ of all jury trials worldwide take place in the United States."); R. HASTIE, S. PENROD \& N. PENNINGTON, INSIDE THE JURY 1 (1983) ("America is distinctive among all nations for the central role accorded the jury trial in its justice system.").

20. See V. HaNS \& N. VIDMAR, supra note 19 , at 31 .

21. See id. at 29.

22. See generally id. at 31-44 (discussing origin and evolution of United States jury system).

23. Id. at 32 .

24. Id.

25. Id. at 35 . 
judging of the hives, hiberties or estates of their fellow subjects."26 Despite Zenger's admitted ownership of the newspaper, the jury acquitted him. ${ }^{27}$

In the decades following the Zenger case, political dissent against British rule mcreased. Trials with political significance increasingly appeared in colomal courts, and the Crown sought to convict political agitators by selecting jurors loyal to England. In 1774, Parliament passed an act that placed jury selection in the hands of the court, a move designed to counteract the Massachusetts Jury Selection Law which attempted to put control of jury selection in the hands of the colonists. ${ }^{28}$

After the Revolution, Americans, and the Framers in particular, were conscious of the jury's importance as a limit against political oppression and as an imstrument for the protection of individual liberty. ${ }^{29}$ The final draft of the Constitution, however, did not specify the size of the jury, unanimity requirements, ${ }^{30}$ selection procedure, or the role of the jury in determining "law" as opposed to "fact."31 This silence about the technical aspects of the jury (i.e. size and unanimity requirements) undoubtedly stemmed from the Framers' efforts to accommodate the divergent common law criminal procedure already practiced by the several states. ${ }^{32}$

In contrast, the Constitution's silence on the jury's role in deciding law as well as fact probably resulted from the Framers' assumption that jurors should "find the verdict according to [their] own best understanding, judgment, and conscience, though in direct opposition to the direction of the court."33 Both the Framers and early Court members recognized the right of jurors to decide verdicts according to conscience rather than according to the law instructed by the court. ${ }^{34}$ And while the increasing expertise of judges eventually led to the demise of the rule that jurors could decide law as well as fact, the Supreme Court continued to recognize that juries have "the power to ignore the judge and effectively nullify the law." 35 The first rationale for vesting nullification

26. Id.

27. Id. at 34 .

28. Id. at 35-36. Under the Massachusetts law, the sheriff chose prospective jurors from a list compiled at town meetings by colonists who screened jury candidates for character and bias. Id.

29. See id. at 36 .

30. R. HAstie, S. Penrod \& N. Pennington, supra note 19 , at 2.

31. See V. HANS \& N. VIDMAR, supra note 19 , at 36-38.

32. See F. Heller, The Sixth AMENDMENT 24 (1951). Examples of the states' varying approaches emerged in the heated ratification debates about the vicinage requirement, see id. at 25 27 , and the right to challenge prospective jurors. See V. HANS \& N. VIDMAR, supra note 19, at 3638; Gutman, The Attorney Conducted Voir Dire of Jurors: A Constitutional Right, 39 BROOKLYN L. REV. 290, 295-97 (1973).

33. See V. HANS \& N. VIDMAR, supra note 19 , at 37.

34. See id. at 37-38.

35. Id. at 39-40. In Sparf \& Hansen v. United States, however, the Supreme Court held that in 
power in juries-that lay judges could not be trusted to know what the law was-may have waned over time. However, the second rationale, that juries inay serve to nullify "unjust rules or their unjust application," ${ }^{36}$ continues in importance to the present day.

\section{Mens Rea and the Jury}

When the Framers wrote the Constitution in the latter half of the eighteenth century, mens rea meant the moral blameworthiness necessary to a finding of criminal guilt. The presence or absence of mens rea was a jury question. It was a prerequisite for any finding of criminal guilt, and a finding of criminal guilt without moral blame was universally recognized as unjust. ${ }^{37}$ Furthermore, while the right to jury trial in criminal cases probably allowed the jury to decide the law as well as the facts, it at least guaranteed a decision by the jury about whether the application of a law to the accused was just or unjust. ${ }^{38}$ Thus, when the Constitution was ratified and the sixth amendment adopted, part of what was guaranteed to criminal defendants was the right to have a jury decide whether they were morally blameworthy.

II

\section{REASONS FOR THE DEVELOPMENT OF STRICT LIABILITY}

Before 1850, proof of some form of mens rea was a prerequisite to conviction for almost all crimes. Today there are many crimes for which no mental element need be proved. ${ }^{39}$ The growing particularization of the inental states required for conviction and the trend toward substitution of lower than traditional requirements of culpabihty have created classes of crimes where, even though a defendant may be morally innocent, the prosecutor does not have to prove that she is morally guilty. These new ideas about guilt and crime have taken root in a country where traditionally "[a] relation between some mental element and punishinent for a harmful act is almost as instinctive as the child's familiar exculpatory 'But I didn't inean to.' "40 In this Section, I explore some of the forces that helped to attenuate the connection between crime and moral guilt.

federal courts "it is the duty of juries in criminal cases to take the law from the court and apply that law to the facts as they find them to be from the evidence." 156 U.S. 51, 102 (1895). The Court firmly rejected the notion that the safety and liberty of citizens would be "more certainly secured" were the jury to retain the legal right "to take the law into their own hands." Id. at 106-07.

36. V. HANS \& N. VIDMAR, supra note 19 , at 42 .

37. See supra notes $2-18$ and accompanying text.

38. See supra notes 19-36 and accompanying text.

39. For instance, liquor and narcotics laws, pure food laws, and traffic laws often impose liability without fault. W. LAFAVE \& A. SCOTT, CRIMINAL LAW $\S 3.8$, at $242 \mathrm{n} .1$ (2d ed. 1986).

40. Morissette v. United States, 342 U.S. 246, 250-51 (1952). 


\section{A. Historical Factors Contributing to the Development of Strict Criminal Liability}

\section{The Industrial Revolution}

One historical reason that legislatures developed lower culpability requirements is because the industrial revolution created a need for effective laws to regulate new types of harmful conduct. The new regulatory statutes generally mcluded no express mental element, and courts interpreted them as "dispensing with the traditional mens rea requirement." 11

In Morissette v. United States, ${ }^{42}$ the Supreme Court recognized the connection between the new and varied harms occurring in an increasingly complex society and the advent of strict criminal liability, ${ }^{43}$ but it did not explam why legislatures chose criminal sanctions rather than civil penalties, such as civil fines. Legislatures may have chosen criminal sanctions because civil remedies historically have been "remedial" rather than pumitive. ${ }^{44}$ That is, legislatures employed the civil sanction only to recompense econonric harms. Thus, they imposed strict civil liability only im areas such as worker's compensation and the regulation of motor vehicles, where actual econonnic harm was a prerequisite to liability. ${ }^{45}$ Because the new set of wrongs created by the industrial revolution required government sanction but did not necessarily inflict economic harm, the new offenses created to deal with these wrongs fit more logically into the penal framework. Indeed, it seems unlikely that legislatures concerned with effectively deterring new social evils would have chosen the legal framework with the higher burden of proof and tighter procedural protections for the accused absent some stricture against imposition of civil hability.

41. Dubin, supra note 12, at 349 n.115.

42. 342 U.S. 246 (1952).

43. Id. at $250-60$. The Court stated:

The industrial revolution multiplied the number of workmen exposed to injury from increasingly powerful and complex mechanisins, driven by freshly discovered sources of energy, requiring higher precautions by employers. Traffic of velocities, volumes and varieties unheard of came to subject the wayfarer to intolerable casualty risks if owners and drivers were not to observe new cares and uniformities of conduct. Congestion of cities and crowding of quarters called for health and welfare regulations undreamed of in simpler times. Wide distribution of goods became an instrument of wide distribution of harm when those who dispersed food, drink, drugs, and even securities, did not comply with reasonable standards of quality, integrity, disclosure and care. ...

While many of these duties are sanctioned by a more strict civil liability, lawmakers, whether wisely or not, have sought to make such regulations more effective by invoking criminal sanctions to be applied by the familiar technique of criminal prosecutions and convictions.

Id. at 253-55 (footnotes omitted).

44. Cf. United States v. Ward, 448 U.S. 242 (1980) (discussing the constitutional import of the distimction betwecn civil and criminal penalties).

45. Cf. Morissette, 342 U.S. at 254 n.13. 


\section{Utilitarianism}

The major philosophical justification for both civil and criminal strict liability is utilitarianism. ${ }^{46}$ The development of utilitarian theory shifted the emphasis in criminal theory from natural law's protection of individual interests to the protection of public and social interests. "As a direct result of this new emphasis upon public and social, as contrasted with individual, interests, courts have naturally tended to concentrate more upon the injurious conduct of the defendant than upon the problem of his individual guilt." 48

In addition to shifting the focus of criminal law from ascertaining guilt to controlling conduct, utilitarian theory also promotes a disregard . for the mental element even in crimes where state of mind is an express part of the offense. ${ }^{49}$ Courts influenced by utilitarian theory were willing to imply states of mind in law, and, as a result, the proof they required to establish certain mental states often had hittle to do with the defendant's actual state of mind. ${ }^{50}$ Finally, utilitarian tlieory's focus on social rather than individual interests may liave inhibited the growth of the mental defenses. ${ }^{51}$

Justice Holmes was perhaps the leading judicial proponent of the utilitarian view. He beheved that "our law exceeds the limits of retribution, and subordinates consideration of the individual to that of the public well-being,"52 that "the general principles of criminal and civil

46. See Note, supra note 1 , at 1534.

47. Cf. Sayre, Public Welfare Offenses, 33 Colum. L. REV 55, 68 (1934) ("[M]odern criminologists are teaching that the objective underlying correctional treatment should change from the barren aim of punishing human beings to the fruitful one of protecting social interests.").

I use the term "natural law" to indicate the legal philosophy followed by the Framers under which "there are certain principles of human conduct, awaiting discovery by human reason, with which manmade law must conform if it is to be valid." H.L.A. HART, THE CONCEPT OF LAW 182 (1961). Natural law adherents beheve that the state exists only to enforce and protect preexisting natural rights. See Horwitz, The Legacy of 1776 in Legal and Economic Thought, 19 J.L. \& EcoN. 621, 624 (1976). This principle is, of course, enshrined in the assertion in the Declaration of Independence that "all men are created equal, and they are endowed by their creator with certain inalienable rights." The Declaration of Independence para. 2 (U.S. 1776). Utilitarians have conducted "a long sceptical campaign . . . against the doctrine of natural and unalienable rights of man," beginning with John Lind's An Answer to the Declaration of the American Congress (1776). Hart, Bentham and the United States of America, 19 J.L. \& ECON. 547, 547 (1976).

48. Sayre, supra note 47 , at 68 .

49. Dubin, supra note 12 , at 350 .

50. Id.; see also Lévitt, Extent and Function of the Doctrine of Mens Rea, 17 ILL. L. REV. 578, 581-86 (1923) (giving examples of how courts infer intent); $i d$. at 586 ("Historically there is a tradition that before such deterrent or pumitive action can be taken the actor must have a certain mental state. So the law sticks that mental state on the act and carries on the tradition.").

51. Dubin, supra note 12, at 350. For example, both legislatures and courts attempted to curtail the insanity, ignorance of the facts, and ignorance of the law defenses. See id. at $350 \mathrm{nn} .119$ 23.

52. O. Holmes, supra note 9 , at 47. 
liability are the same," 53 and that "justice to the individual is rightly outweighed by the larger interests on the other side of the scales." 54 Indeed, Holmes went so far as to claim that the only reason the criminal law ever looks to the defendant's state of mind is to determine if he "was in such a state that he could not be expected to remember or be influenced by the fear of purishment." 55 Recognition of even such a limited exception for nonculpable mental states, however, shows that Holmes did retam, at least to some degree, some of the old, moral, natural law ideals. $^{56}$

Under a strict utilitarian view, punishing a person without fault is justified if the social benefit of deterring others is greater than the harm to the individual. The development of utilitarian theory, its effect on theories of punishment, and its espousal by such a renowned jurist as Holmes contributed to broad judicial acceptance of strict criminal hability.

\section{Psychiatry}

The influence of determinisin and new knowledge about the way the human mind works inay also have influenced courts' departure from traditional mens rea doctrine. While Holmes supported his objective view of criminal law with the observation that we never can determine an actor's actual state of mind because we inust rely on external phenomena, ${ }^{57}$ perhaps the greater difficulty for traditional mens rea analysis arose froin inodern atteinpts to understand mental processes.

The developinent of sciences that could to soine extent trace the hidden causes of an actor's behavior altered popular conceptions of moral choice. People began seeing individual freedom, and hence individual responsibility, as inuch more himited than previously believed. ${ }^{58}$ On the one hand, this view tightened the connection between blameworthiness and punishment, because factfinders could take imto account the hidden causes of an offender's behavior both in assessing the guilt of a criminal defendant and in deciding her punishment. ${ }^{59}$ On the other hand, if volitional conduct is essential to moral culpability, it beconnes problematic to condemn soineone as blameworthy when the volitional character of all

53. Id. at 44 .

54. Id. at 48 .

55. Id. at 62 .

56. Even so, Jerome Hall claimed that Holmes's "uncompromising support of the prevention theory required rejection of a moral basis for criminal liability." Hall, Interrelations of Criminal Law and Torts: I, 43 CoLUM. L. REv. 753, 763 (1943). Hall also noted Holmes's ahistorical view of strict liability-Holmes thought that grounding criminal law on a moral basis was primitive, and he saw strict liability as a completely new development. Id. at 761-62.

57. O. HolmEs, supra note 9, at 50.

58. See S. Freud, INTROdUctory LeCtURES IN Psychoanalysis 28 (1966).

59. Hall, supra note 56 , at 776 . 
conduct is called into question. If "to understand is to forgive," the development of a determimistic psychiatry may have fueled a new societal repugnance at usmg criminal law to exact punishment for inoral wrong. ${ }^{60}$ Society became ainbivalent about its right to condemn, and this ambivalence added to the influence of those endorsing the deterrent and utilitarian theories that justify strict criminal hability. ${ }^{61}$

Another result of the increased ability to assess a defendant's actual subjective inental state is the tendency to view the mens rea element as a strictly factual judgment rather than as a moral assessment. Even for traditional common law crimes, courts do not ask today's jurors to pass judgment on a defendant's blameworthiness, but instead ask thein only to resolve the factual issue of what mental event took place in the accused's mimd at the time she performed the prohibited act. The legislature decides what mental event, combined with a particular act, merits punishment. ${ }^{62}$ Thus, the question asked in courts about an accused's mental state is no longer "Is this the sort of person who deserves societal condemnation?" Instead, it becomes a factual question: "Is this the sort of person who was capable of entertaining or did in fact entertain a certain kind of thought?"63

\section{Demise of Substantive Due Process}

Another factor that may have prompted judicial acceptance of strict criminal liability is the demise of substantive due process and the Court's accompanying unwillingness to substitute its judgment for the judgment of the legislature. The Court has expressed the fear that imposing a due process requirement of a mental element would mean substituting its morality for the morality of society as expressed by the legislature. ${ }^{64}$ The Court's reluctance to impose a due process mental element requirement may be animated by the fear expressed by Justice Frankfurter in his dissent in Lambert v. California, ${ }^{65}$ the only case in which the Supreme

60. "It is hard to make moral judgments, to use words like good and bad." D. LESSING, A Small Personal Voice 5 (1974), quoted in Allen, Criminal Law and the Modern Consciousness: Some Observations on Blameworthiness, 44 TENN. L. REV. 735, 740 (1977).

61. Cf. Allen, supra note 60 , at 738 ("Some have perceived an irony in the fact that the great Faustian achievements of scientific thought appear to have had the unexpected consequence of reducing the importance of intellect and rationality in modern theories of human behavior.").

62. Cf. W. LAFAVE \& A. SCOTT, supra note 39, at $\$ 3.4($ a), at 212-13 (discussing development of statutorily defined mental states).

63. See Comment, Legal and Psychiatric Concepts and the Use of Psychiatric Evidence in Criminal Trials, 73 CALIf. L. REv. 411, 415-16 (1985).

64. Liparota v. United States, 471 U.S. 419,427 (1985) ("[B]ecause of the seriousness of criminal penalties, and because criminal punishment usually represents the inoral condemnation of the community, legislatures and not courts should define criminal activity.") (quoting United States v. Bass, 404 U.S. 336, 348 (1971)); see also Morissette v. United States, 342 U.S. 246, 254 n.14 (1952).

65. 355 U.S. 225, 230 (1957) (Frankfurter, J., dissenting). 
Court has imposed an affirmative due process limit on strict liability. Frankfurter noted the vast number of strict liability crimes then in existence $^{66}$ and suggested that if the Court created a constitutional requirement of a certain mental element as a prerequisite to criminal conviction, "a whole volume of the Umited States Reports would be required to document in detail the legislation in this country that would fall or be impaired." $67 \mathrm{He}$ concluded by expressing his confidence that the decision, which struck down a Los Angeles felon registration statute, ${ }^{68}$ would "turu out to be an isolated deviation from the strong current of precedents-a derelict on the waters of the law." "69

Frankfurter need not have feared. The Court's unwillingness to step on the toes of legislators has played an important role in the development of Court doctrine on the mental element in crime. ${ }^{70}$

\section{B. The Court's Mens Rea Doctrine}

The historical developments noted above have combined with the trend toward codification of criminal law in all United States jurisdictions to create a mens rea jurisprudence that almost completely ignores the important function mens rea historically served: protecting morally innocent individuals from punishment at the hands of the state. The Supreme Court's treatment of three distinct areas-the particularization of mental states, the legislative trend toward shifting the burden of proof on the mental eleinent, and the acceptance of strict hability crimesreveals its blindness to the role mens rea played in protecting individuals from state power.

\section{Particularization of Mens Rea}

All common law crimes required proof of some inental eleinent, although the exact state of mind required differed from crime to crime. These mental elements became much more particularized as legislatures codified criminal law. Today, some jurisdictions have abohished common law crimes, ${ }^{71}$ and statutory crimes, unknown to the common law, far outnumber the original common law crimes. ${ }^{72}$

At common law, crimes required either "general intent" or "specific intent." These terms were the source of considerable confusion. Sometimes specific intent meant the intent to bring about the forbidden result,

66. Id.

67. Id. at 232.

68. See infra text accompanying notes 114-16.

69. Lambert, 355 U.S. at 232 (Frankfurter, J., dissenting).

70. See infra notes 110-23 and accompanying text.

71. As of 1972, about 20 states had abolished common law crimes. W. LAFAvE \& A. SCOTT, Criminal Law § 9, at 61 (1972).

72. W. LAFAVE \& A. SCOTt, supra note 39, at § 3.4(a), at 213. 
while general imtent meant the intent to do an act with the knowledge that such an act would likely cause the forbidden result. Sometimes general intent meant a general notion of "guilty mind," while specific intent ineant the mental state required for conviction of a particular crime. ${ }^{73}$

In recent years, many states have adopted a new analysis of mens rea. This approach, developed in the Model Penal Code, replaces the traditional general-specific intent dichotomy with a hierarchy of culpable states of mind. ${ }^{74}$ The codification of criminal law, im conjunction with this new analysis, has resulted in statutorily defined crimes im which " "the question of the kind of culpability required to establish the coinmission of an offense [must] be faced separately with respect to each inaterial element of the crime." "775

While the creators of level-of-culpability analysis meant to reduce the confusion and ainbiguity of the specific-general intent dichotony, their framework has created new probleins because courts interpreting the newly codified crimes inust determine which words in a statute are modified by the culpability word. Two writers on the subject dennonstrate the problein through the following example:

What, for instance, does "knowingly" modify in a sentence from a "blue sky" law criminal statute punishing one who "knowingly sells a security without a permit" from the securities commissioner? To be guilty must the seller of a security without a permit know only that what he is doing constitutes a sale, or must he also know that the thing he sells is a security, or must he also know that he has no permit to sell the security he sells? As a matter of grammar the statute is ambiguous; it is not at all clear how far down the sentence the word "knowingly" is intended to travel .... .

While it is possible to draft a statute to minimize such ambiguities, legislatures rarely do so. This is not at all surprising: ainbiguity in a statute is often an essential element in its passage. When faced with such a statute, however, courts inust develop rules of construction in order to eliminate the ambiguity and apply the law in a principled nnanner. The Supreme Court has developed such rules of construction, but as I will show, courts can use these rules to support the very result they were intended to avoid-legislation by judicial fiat.

The Court's first principle of construction is that legislative intent prevails over principles of common law or opinions of influential coin-

73. United States v. Bailey, 444 U.S. 394, 403 (1980).

74. See, e.g., id. at 403-04 ("The different levels in this hierarchy are commonly identified, in descending order of culpability, as purpose, knowledge, recklessness, and neghigence.").

75. Id. at 404-06 (quoting MODel PenAl CODE $§ 2.02$ comment 1, at 123 (Tent. Draft No. 4, 1955)).

76. W. LAFAVE \& A. ScoTr, supra note 39, at § 3.4(b), at 214. 
mentators. ${ }^{77}$ Where statutory language is ambiguous, courts turn to legislative history to determine legislative intent. Often there is no history, or the history that exists is ambiguous or conflicting.

The lack of history or ambiguity in existing history can lead to three probleins. First, since the issue arises only where the language can be interpreted in more than one way, the prosecution usually argues that the legislature intended that the culpability term modify only the word immediately next to it, while the defendant argues that the legislature wanted the culpability term to modify all words following it. ${ }^{78}$ The government's interpretation can transform a statute that the legislature intended to require some mental eleınent into an essentially strict liability crime. $^{79}$ Thus, in the "blue sky" law example, a person who knows he is making a sale would be hable even though he does not know that he is selling a security, and he has no reason to know that the law forbids selling a security without a permit. Second, where soine legislative history does exist, there is the danger that a court will use it to support its own mtuition about what the statute should inean. Finally, where no legislative history exists on the issue of intent, courts sometimes will Inaintain that the overriding importance of the legislative purpose supports the inost restrictive possible reading of the statute. For exainple, in United States $\boldsymbol{v}$. Margraf, ${ }^{80}$ the defendant was convicted of atteinpting to carry a concealed deadly or dangerous weapon aboard a coininercial aircraft. $^{81}$ In upholding the defendant's conviction, the Third Circuit held that while the defendant had to be aware that he was carrying the itein at issue (a pocket knife), he did not have to know that what he was carrying was classified as a deadly weapon and he did not have to intend to use it for an illegal purpose. ${ }^{82}$ In reaching its result, the court did not rely upon legislative history about the inental eleinent but instead focused upon history about the importance of preventing air piracy. ${ }^{83}$ On that

77. Bailey, 444 U.S. at 406.

78. See, e.g., Liparota v. United States, 471 U.S. 419, 423 (1985).

79. I use the term "strict liability" to denote crimes where the defendant may have no knowledge of wrongdoing. Although the defendant may be conscious that he is performing a particular act, lie may not know either that the act itself or its consequences are illegal or nuorally wrong. Courts sometimes treat any requirement of knowledge as relnoving a statute from the strict hability category. See Mueller, On Common Law Mens Rea, 42 MINN. L. REv. 1043, 1051-52 (1958) (noting that to call any knowledge the equivalent of mens rea "confound[ed]" the niens rea requirement with the inental process ingredient of any act).

80. 483 F.2d 708 (3d Cir.), vacated and remanded on other grounds, 414 U.S. 1106 (1973).

81. The statute under which he was charged provided: "whoever attempts to board ... an aircraft while laving on or about his person a concealed deadly or dangerous weapon, shall be fined not inore than $\$ 1,000$ or imprisoned not nore than one year, or both." 49 U.S.C. $\S 1472$ (1) (1971).

82. Margraf, 483 F.2d at $710-11$.

83. Id. at 710 (quoting H.R. REP. No. 758, 87th Cong., 1st Sess., reprinted in 1961 U.S. CoDE Cong. \& ADMIN. NEwS 2563). The Third Circuit responded to the appellant's arguntent that this stringent construction of the statute would allow prosecutions of Boy Scouts with pocket knives by 
basis, the Margraf court construed the statute under which the defendant was convicted as creating a strict hability crime.

If there is no legislative history, or if the court decides that the history does not support any particular reading, the Court turns next to common law principles. These principles usually support the criminal defendant's reading of the statute. Thus, in construing a food stamp statute containing the word "knowingly," the Supreme Court in Liparota $v$. United States ${ }^{84}$ noted that offenses requiring no mens rea have a generally disfavored status because of the historical importance of the mens rea requirement. ${ }^{85}$ The Court stated that construing a statute to require inens rea was especially appropriate where strict liability would "criminalize a broad range of apparently innocent conduct." common law principle, that " ambiguity concerning the ambit of criminal statutes should be resolved in favor of lenity," "87 supported the Court's holding that "knowingly" noodified more than just the verb imınediately following it.

Where neither legislative history nor common law principles help guide interpretation of a statute, the Court conipares the statute at issue with surrounding or analogous statutes. It is difficult to reconcile the conflicting results of such coinparisons. In Liparota, the Court found the fact that another section of the same statute exphcitly required knowledge of wrongdoing was "too slender a reed to support the atteinpted distinction" and render the section at issue a strict hability provision. ${ }^{88}$ In Margraf, however, the Third Circuit found that because another section of the statute at issue explicitly imposed a knowledge of wrongfulness requireinent, Congress intended to dispense witl such a requirement in the section of the statute at issue in that case. ${ }^{89}$

The Court's final principle of construction is to distinguish between common law crimes and so-called "public welfare" offenses. ${ }^{90}$ The Court maintains a strong presumption that Congress did not intend to omit a

stating that "courts will have to balance the potential harm to innocent passengers with what could be an unknowing act by a defendant." Id. at 712. The defendant in Margraf was a musician who used the knife to work on band equipment. Id. at 716.

84. 471 U.S. 419 (1985).

85. Id. at $425-26$.

86. Id. at 426 .

87. Id. at 427 (quoting Rewis v. U.S., 401 U.S. 808, 812 (1971)).

88. Id. at 429; see also Dennis v. United States, 341 U.S. 494, 499 (1951) (presence of intent element in one subsection of statute insufficient to show congressional desire to eliminate intent element in related subsection). The dissent in Liparota felt that the absence of any discussion of an intent elenent in the legislative history supported a strict liability reading. Liparota, 471 U.S. at 439 40 (White, J., dissenting).

89. United States v. Margraf, 483 F.2d 708, 710 (3d Cir), vacated and remanded on other grounds, 414 U.S. 1106 (1973).

90. Sayre coined the term "public welfare" offense to denote petty statutory offenses punishable regardless of the actor's state of mind. Sayre, supra note 47, at 56 n.5, 67 . 
mens rea requirement for offenses that were common law crimes. ${ }^{91}$ For public welfare offenses, however, the Court is more willing to infer that the legislature intended to impose strict hability or restrict the elements of the crime for which the prosecution must prove a mental element even in the absence of legislative history to support such a reading. ${ }^{92}$ The Courts of Appeal had extended this "public welfare" exception to a presumption of strict liability for all regulatory offenses, ${ }^{93}$ but in Liparota the Supreme Court limited the exception to cases where "Congress has rendered criminal a type of conduct that a reasonable person should know is subject to stringent public regulation and may seriously threaten the community's liealtli or safety." 94

To summarize, mens rea requirements became increasingly particularized witl the codification of criminal law. Today the requisite inental element may be different not only from crime to crime but also from element to element witlin a crime. Often the legislature's use of an "intent" word in a statute is ambiguous, and the Court has adopted rules of construction to cope with the ambiguity. While some of the rules, particularly those derived from common law mens rea principles, serve to preserve a knowledge of wrongdomg requirenent, the rule that legislative intent prevails allows courts to read a statute that could be interpreted as requiring knowledge or purpose as creating a strict liability crime.

While legal theorists and practitioners may have intended that the particularization of mental states result in "more predictable and therefore less arbitrary law," miglit not serve this purpose. First, because courts can manipulate rules of construction when interpreting statutory language, particularization does not necessarily make law and its enforcement predictable. One cannot predict pumislıment for conduct not known to be harmful or forbidden. Second, the articulation of required mental states often does not serve the law's traditional function of differentiatimg harmful conduct by the morally guilty from harmful conduct by the morally innocent.

91. See, e.g., Morissette v. United States, 342 U.S. 246, 261-63 (1952) (rejecting government's argument that Congress intended not to require criminal intent in a conversion statute the Court found akin to the common law crime of larceny).

92. See, e.g., United States v. Freed, 401 U.S. 601, 607-10 (1971) (interpreting statute forbidding possession of unregistered firearms as not requiring knowledge that the firearm was unregistered).

93. E.g., United States v. F.M.C. Corp., 572 F.2d 902 (2d Cir. 1978) (violation of Migratory Bird Treaty Act); United States v. Eme, 576 F.2d 212 (9th Cir. 1978) (income tax violation).

94. Liparota v. United States, 471 U.S. 419, 433 (1985).

95. Sayre, supra note 2 , at 1020. 


\section{Shifting the Burden of Proof of Intent}

Prompted by concern that legislatures would extend strict liability from "petty offenses" to serious crimes, Sayre suggested the less drastic measure of retaining the mens rea element but shifting the burden of its proof to the defendant. ${ }^{96}$ He felt that the use of strict hability had its place, but suggested that its use be restricted to situations where the legislature's primary concern was regulating the social order rather than punishing, individual wrongdoers, and to crines for which the penalty was light and no imprisonment could be imposed. ${ }^{97}$ Sayre suggested that if proving mens rea was too onerous to assure enforceinent of a law for which serious penalties are imposed, the courts could meet the problem "by shifting to the shoulders of the defendant the burden of proving a lack of guilty intent."98 Legislatures have eagerly adopted Sayre's suggestion, ${ }^{99}$ and although the Supreme Court had placed soine limits on the legislature's discretion to shift the burden of proof to the defendant, recent cases suggest that the limits are very narrow.

The Court's broad view of the state's power to shift the burden of proof to the defendant followed an earlier decision that had proscribed the power of the state to reallocate the burden of proof. In Mullaney $v$. Wilbur, ${ }^{100}$ the State of Maine had required a defendant charged with murder to prove that he acted in the heat of passion on sudden provocation in order to reduce a charged homicide to inanslaughter. However, the Supreme Court held that, by requiring the defendant to show absence of matice by proving provocation, the Maine law violated due process. In apparent contradiction, the Court two years later upheld a New York murder statute in Patterson v. New York ${ }^{101}$ that required a defendant to prove by a preponderance of the evidence that he acted under the influence of an extreme emotional disturbance in order to reduce a homicide to manslaughter.

The Patterson Court insisted that it was not overruling Mullaney. It explained that a state normally has the power to allocate burdens of production and persuasion. ${ }^{102}$ The difference between Mullaney and Patterson, the Court suggested, was that the Maine statute included makice as an elenient of second degree murder and presuined malice upon a showing that the defendant intended to cause the death of the victim, whereas

96. Sayre, supra note 47 , at 70 ("The group of offenses punishable without any proof of criminal intent must be sharply limited.").

97. Id. at 72 .

98. Id. at 82.

99. See Jeffries \& Stephan, Defenses, Presumptions, and Burden of Proof in the Criminal Law, 88 YALE L.J. 1325, 1330-31 \& nn.9-12 (1979).

100. 421 U.S. 684 (1975).

101. 432 U.S. 197 (1977).

102. Id. at 201-02 (citations omitted). 
the New York statute defined second degree murder as killing with intent to cause death but omitted the element of malice. ${ }^{103}$ In the latter case, the statute's requirement that the defendant affirmatively prove lack of malice in order to mitigate pumshment did not violate due process requirements. The Court thus himited Mullaney to a procedural requirement rather than a requirement of substantive fairness. The Court did note that there are some substantive limits that restrain a state from reallocating burdens of proof by labelling intent elements of crimes as affirmative defenses. But it did not define those limits. ${ }^{104}$

The recent Supreme Court decision in Martin v. Ohio ${ }^{105}$ indicates that the Court will apply a purely formal, procedural analysis rather than a functional analysis to determine whether a state has passed the Patterson test. The Martin Court upheld against the defendant's due process challenge an Ohio law that required the defendant in a homicide case to prove self-defense by a preponderance of the evidence. Under Ohio law, the crime of aggravated murder with which the defendant was charged required that the act be done "purposefully, and with prior calculation and design."106 The jury was instructed both that the state must prove all elements of the crime beyond a reasonable doubt, and that the defendant had to prove that she acted in self-defense by a preponderance of the evidence. ${ }^{107}$ The Court upheld the law because it believed that the jury would understand from these instructions that it could consider defendant's self-defense evidence in determining whether the state had met its burden of proving the crime's intent element beyond a reasonable doubt. Therefore, requiring defendant affirmatively to prove self-defense did not shift the burden of proof of the crime's intent element to the

103. Id. at 215 .

104. Id. at 210. In Holloway v. McElroy, 632 F.2d 605 (5th Cir. 1980), cert. denied, 451 U.S. 1028 (1981), the Fifth Circuit suggested that the Mullaney-Patterson rule protected substantive as well as procedural values. The court noted that "in applying the due process clause to the States' definition of criminal offenses and allocation of burdens of persuasion, there are both procedural fairness and substantive fairness components to the analysis." Id. at 624. The substantive value protected by the Mullaney-Patterson rule is "that no person should be convicted when there remains a reasonable doubt as to the truth of any of the essential elements included in the definition of the crime." Id. The procedural rule the Supreme Court established to protect this substantive value requires the prosecution to prove beyond a reasonable doubt every element included in the definition of a crime. Id. The Holloway court also noted that in order to protect innocent defendants, courts must consider both the selection of facts that the prosecution must prove and the certainty with which these facts must be proven. Id. (citing Jeffries \& Stephan, supra note 99, at 1347). Thus, the Holloway court concluded that, after Patterson, federal courts should apply a functional analysis to their burden-shifting inquiries. The inquiry in a particular case would be whether the state really had excluded the mental element the state required the defendant to affirmatively disprove, as in Patterson, or whether the state functionally had incorporated as an essential element of the crime the element the defendant must disprove, as in Mullaney. Id. at 628.

105. 107 S. Ct. 1098 (1987).

106. Id. at 1100 (quoting OHIO Rev. CODE ANN. § 2903.01 (Page 1982)).

107. Id. at 1101-02. 
defendant. ${ }^{108}$

The Martin Court's supported its conclusion by stating that a jury could find that a defendant had killed purposefully and with prior calculation, yet in self-defense. ${ }^{109}$ This result is possible, however, only if the crime's intent element includes no inoral connotation. For example, an Ohio defendant may decide in advance that she will kill her husband if he puts her in imminent danger of death or great bodily harm under circumstances in which she has no duty to retreat or to avoid the danger. Even though a decision to kill under such circumstances is not necessarily morally wrong, the Ohio jury must convict such a defendant of aggravated murder if she cannot prove self-defense by a preponderance of the evidence. The Ohio statute therefore requires that the prosecution prove beyond a reasonable doubt intent to kill, but places on the defendant the burden of showing that her intent was not wrongful. If a state carefully drafts its murder statute so that juries only need find as a factual inatter that defendants intended to kill their victims and avoids using terms such as "malice," or "wrongful," its juries can convict morally blameless defendants of murder.

To summarize, a legislature may not require a court to presume an element of intent defined in a crimmal statute upon a showing of other "act" elements of the crime (although juries may, of course, infer intent from the proof of such facts). Legislatures, however, may lower the level of culpability traditionally required at common law for conviction of a particular felony, and require the defendant to prove a particular mental state (e.g., provocation, insanity, or self-defense) in order either to mitigate or to eliminate a finding of crimmality. The Supreme Court has suggested that there are limits on a state's freedom to redefine crimes, although it is unclear after Martin what these himits are. Pushed to their logical limits, Patterson and Martin would allow a state to define murder as "killing with intent to cause death," and eliminate all affirmative defenses, thereby making the culpability of the killer's state of mind completely irrelevant.

\section{The Court's Acceptance of Strict Liability Crimes}

\section{a. Supreme Court Doctrine}

The Supreme Court has long held that the creation of strict liability crimes does not violate due process: "[I]n the prohibition or punishment of particular acts, the State may in the maintenance of a public policy provide 'that he who shall do them shall do them at his peril and will not

108. Id. at $1102 \& \mathrm{n} . * *$.

109. Id. at 1102 . 
be heard to plead in defense good faith or ignorance." "110 Indeed, both state and federal governments now impose strict liability in a wide variety of criminal contexts. ${ }^{11}$

As previously discussed, the Court's determination of whether a legislative body incorporated a strict liability component into a particular law is a matter of statutory construction, guided primarily by an analysis of legislative intent. The reason the Court offers for presuming mens rea in crimes that originated at common law, however, shows that it remains ambivalent about imposing strict criminal liability. As the Court explained in Morissette v. United States:

The contention that an injury can amount to a crime only when inflicted by intention is no provincial or transient notion. It is as universal and persistent in mature systems of law as behef in freedom of the human will and a consequent ability and duty of the normal individual to choose between good and evil. A relation between soine mental element and purishment for a harmful act is almost as instinctive as the child's familiar exculpatory "But I didn't mean to," . . .

Crime, as a compound concept, generally constituted only from concurrence of an evil-meaning mind with an evil-doing hand, was congenial to an intense individualisin and took deep and early root in American soil. As the states codified the comnnon law of crines, even if their enactments were silent on the subject, their courts assumed that the omission did not signify disapproval of the principle but merely recognized that intent was so inherent in the idea of the offense that it required no statutory affirmation. ${ }^{112}$

It is important to remember, however, that Morissette merely enunciated a rule of statutory interpretation. Although the Court recognized that the inens rea requirement protected values important to early Americans, it refused to announce a constitutional rule prohibiting Congress from transforming a coinmon law crime into one imposing strict liability. In fact, by approving state laws that lower the level of culpability necessary for conviction under the common law, ${ }^{113}$ the Court has in effect already given states permission to codify the intent element, even for hoinicide, in terms that approach strict liability.

The Court has announced soine substantive linits on the imposition of strict liability. In Lambert $v$. California, ${ }^{114}$ the ordinance at issue required anyone who had ever been convicted of a crime punishable in California as a felony to register with the County when the person would

110. United States v. Balint, 258 U.S. 250, 252 (1922) (quoting Shevlin-Carpenter Co. v. Minnesota, 218 U.S. 57, 70 (1910)).

111. See W. LAFAVE \& A. SCOTT, supra note 39 , at $\$ 3.8$, at $242 \&$ n.1.

112. 342 U.S. 246, 250-52 (1952) (footnotes omitted).

113. See supra notes $96-109$ and accompanying text.

114. 355 U.S. 225 (1957). 
be in Los Angeles for a period of more than five days. Failure to comply was an offense punishable as a felony. The Court held that, even though "[t]here is wide latitude in the lawmakers to declare an offense and to exclude elenients of knowledge and diligence fronı its definition," 115 the statute violated due process as apphed to a person who had no knowledge of the duty to register because there was absolutely nothing that might cause a person to inquire about the need to register. ${ }^{116}$ The Court distinguished the defendant's "wholly passive" conduct fron the "commission of acts, or the failure to act under circunistances that should alert the doer to the consequences of his deed."117

While Lambert held that ignorance of the law sometimes is an excuse, it did not hold that ignorance is an excuse under all circuinstances. A court thus may convict a person who has committed no overt act, and who is without imtent or knowledge of blameworthiness. In United States v. Park, ${ }^{118}$ the Court held that a corporate officer who has " 'a responsible share in the furtherance of the transaction which the statute outlaws" " may be criminally hable even if she does not know of the violation. ${ }^{119}$ The omission need not even amount to negligence; it is enough if "the agent had the power to prevent the act complained of."120 The Park Court observed that certain businesses " 'touch phases of the lives and health of people" "who, "in the circumstances of modern industrialism, are largely beyond self-protection." "121 In such cases, Congress has a right to eliminate the conventional requirement of awareness of wrongdoing and to impose an unusually high duty of care, because "[t]he accused, if he does not will the violation, usually is in a position to prevent it with no more care than society might reasonably expect and no more exertion than it inight reasonably exact from one who has assunied his responsibilities." 122

The recent Liparota case suggests that the Court will limit the imposition of this high standard of care (which in effect dispenses with the actus reus as well as the mens rea requirement) to "conduct that a reasonable person should know is subject to stringent public regulation and may seriously threaten the community's health or safety"123 (exainples of such conduct include possession of firearms and the sale of adulterated

115. Id. at 228 .

116. Id. at $228-29$.

117. Id. at 228 .

118. 421 U.S. 658 (1975).

119. Id. at 670 (quoting Morissette v. United States, 342 U.S. 246, 258 (1952)); but see id. at 672 ("The concept of a 'responsible relationship' to, or a 'responsible share' in, a violation of the Act indeed imports some measure of blameworthiness.").

120. Id. at 671 .

121. Id. at 668 (quoting United States v. Dotterweich, 320 U.S. 277, 280 (1943)).

122. Id. at 671 (quoting Morissette v. United States, 342 U.S. 246, 256 (1952)).

123. Liparota v. United States, 471 U.S. 419,433 (1985). 
food or drugs). The Liparota language suggests that the due process clause protects against the imposition of criminal liability at least where the actor does not realize that her conduct violates the law and a reasonable person would not expect the conduct to be highly regulated. But it is not clear what other limits the due process clause imposes on strict criminal liability. ${ }^{124}$

\section{b. Confusion in the Circuit Courts}

The Courts of Appeal disagree about whether a legislature may create a strict liability felony offense, impose strict liability with a penalty of imprisonment, or impose a fine under a strict liability statute so excessive as to violate due process.

For example, in McQuoid $v$. Smith, ${ }^{125}$ the defendant alleged that his one year mandatory prison sentence for carrying an unlicensed firearm in Massacliusetts constituted cruel and unusual punishment and denied him equal protection where he was unaware of the need for a license and was carrying the gun without criminal intent. The area of regulation, possession of firearms, was one in which the legislature clearly could impose strict liability under Liparota. ${ }^{126}$ The question for the McQuoid court thus was whether the imposition of a one year irreducible prison sentence in the strict liability context violated due process. The First Circuit rejected the defendant's due process objection, answering that the proper inquiry was not whether the sentence violated due process but "whether the penalty is so grossly disproportionate as to violate the eighth amendment." 127 In analyzing the eighth amendment issues, however, the court failed to factor into its analysis that punishment was being imposed on one without a "guilty mind." It merely noted that, although the sentence was severe and at variance with the usual pattern of discretionary sentencing, "deterrence is a legitimate penological goal" and "in light of the significant dangers associated with uncontrolled weapons, the mandatory one-year minimum sentence is not so grossly disproportionate to prevailing norms and sensibilities as to violate the eighth amendment."128

In contrast to McQuoid, the Sixth Circuit in United States v.

124. For example, due process may limit the severity of the penalty imposed under strict liability statutes. In discussing "public welfare" offenses in Morissette v. United States, the Court noted that for strict liability offenses "penalties commonly are relatively small, and conviction does no grave damage to an offender's reputation." 342 U.S. 246, 256 (1952). However, in the cases in which the Court has upheld the imposition of strict liability, it has been frustratingly silent about the penalties imposed by the lower courts.

125. 556 F.2d 595 (1st Cir. 1977) (defendant was taking a gun to a gunshop to sell it for money to buy his high school ring).

126. See supra note 123 and accompanying text.

127. McQuoid, 556 F.2d at 599.

128. Id. at 597 . 
Wulff ${ }^{129}$ affirmed the dismissal of a felony indictınent for violation of the Migratory Bird Treaty Act on the grounds that it violated due process. The court held that, for felonies, "the absence of a requireinent that the government prove soine degree of scienter violates the defendant's right to due process." 130 Since the court had previously interpreted the statute to create a strict liability crime in cases involving misdenneanor penalties, the only issue was what meaning the court should give the dicta from Morissette v. United States, which suggested that there must be a relationship between the defendant's mental state and the punishment iinposed by a court. ${ }^{131}$ After examining Morissette and other cases, the court concluded that strict liability "does not violate the due process clause where (1) the penalty is relatively small, and (2) where conviction does not gravely besmirch." 132 The statute at issue violated due process because a felony conviction irreparably damages the defendant's reputation and deprives her of many of her civil rights for life. Thus, the potential penalty was not "relatively sinall." 133

In sun, the Supreine Court allows legislatures wide discretion to create criminal strict liability. The discretion is not without liınits, however, and in Lambert, the Court held that the due process requireinent of notice is one such limit. Just what the other limits will prove to be is uncertain: the Courts of Appeal are divided as to whether prison sentences and the stigma of a felony conviction also cross the due process line.

129. 758 F.2d 1121 (6th Cir. 1985).

130. Id. at 1125 .

131. Morissette v. United States, 342 U.S. 246, 250-52 (1952).

132. Wulf, 758 F.2d at 1125 .

133. Id. At the time the Sixth Circuit decided Wulff, the Migratory Bird Treaty Act provided for a maximum sentence of a $\$ 2000$ fine, or two years imprisonment, or both. Id. at 1122 . In a footnote, the court quoted Morissette as follows: "the infamy is that of a felony, which, says Maitland, is '. . a as bad a word as you can give to a man or thing.' " Id. at 1125 n.2 (quoting 342 U.S. at 260). The Pennsylvania Supreme Court applied similar reasoning in Commonwealth v. Koczwara, $397 \mathrm{~Pa}$. 575, 155 A.2d 825 (1959), where it held unconstitutional the imposition of a prison sentence under a strict liability law, though approving imposition of a $\$ 500$ fine. One of the dissenting opinions objected to finding the defendant guilty of any crime:

[The majority decisionl sustains the conviction of a person for acts admittedly not committed by him, not performed in his presence, not accomplished at his direction, and not even done within his knowledge. It is stigmatizing him with a conviction for an act which, in point of personal responsibility, is as far removed from him as if it took place across the seas. The Majority's decision is so novel, so unique, and so bizarre that one must put on his spectacles, remove them to wipe the lenses, and then put them on again in order to assure himself that what he reads is a judicial decision proclaimed in Philadelphia, the home of the Liberty Bell, the locale of Independence Hall, and the place where the fathers of our country met to draft the Constitution of the United States, the Magna Charta of the liberties of Americans and the beacon of hope of mankind seeking justice everywhere.

Id. at 589-90, 155 A.2d at 832 (Musmanno, J., dissenting); cf. United States v. Park, 421 U.S. 658 (1975) (decided a scant fifteen ycars later). 


\section{III}

\section{Reasons AtTacks on Strict Liability Have FaILED}

As noted, the Supreme Court has limited the imposition of strict hability on grounds of the due process requirement of notice. ${ }^{134}$. Similarly, the Court announced in Patterson that if a state mcludes a mental state as an element of a crime, the state may not create a presumption that the mental state is established upon proof of the other elements and then require the defendant to prove a mental state that negates the one presumed. These rules, as well as some rules of statutory construction of "intent" words, do offer some protection for the unblameworthy criminal defendant. The question is whether these protections are enough.

Although the Court essentially has adopted a stance of deference to the legislature in the development of its strict liability doctrine, commentators almost umversally condemn this posture because it allows conviction of the inorally innocent. ${ }^{135}$ Some critics have focused their attacks on the moral problems of imposing punishinent without proving knowledge of wrongdoing or on the relationship between mens rea and principles of punishinent. Other critics have argued that, in the long run, abandoning a mens rea requirement will undermine the foundation of criminal law-the assent of the people. In short, most attacks on strict hability have come down to a plaintive "But it's wrong!" In this light, the Supreme Court perhaps is correct in refusing to substitute its judgment for that of Congress and state governments.

A few coinmentators have recognized that the traditional concept of criminal responsibility plays a particularly important role in a democracy: it limits "the power of the state to abridge the liberty of the individual." 136 Francis Allen articulated the principle:

Attention may shift from the purposes of criminal punishment to the problem of imposing proper restraints on the state as it defines and enforces the criminal law. Thus it may be asserted that the state must not impose criminal sanctions on an accused unless his behavior is fairly subject to moral condemnation. ${ }^{137}$

Allen recognized that societies may seek to achieve legitimate objectives, for example deterrence and social defense, by punishing criminal behavior. He concluded, however, that the requirement of blameworthiness should be a necessary condition to a state's achievement of these admittedly legitinate objectives. ${ }^{138}$

Even Allen, who acknowledges the political function of the mens rea

134. See supra notes 114-16 and accompanying text.

135. See, e.g., Morissette, 342 U.S. at 254 n.14 (citing various critical commentators).

136. Dubin, supra note 12 , at 343.

137. Allen, supra note 60 , at 745 .

138. Id. at $745,761-62$. 
requirement, views the requirement as a limit on the legislatures' freedom to define crimes. Commentators have suggested various approaches the Court might use to determine whether the legislature has exceeded the limit. ${ }^{139}$ The choice among these approaches, however, depends on the Court's theory of criminal responsibility. Thus, before it can adopt any of the proposed theories, the Court must develop a coherent constitutional philosophy of criminal responsibility, a task that-perhaps not unwisely-it has been unwilling to assume.

There are three problems with an approach that asks the Court to develop a theory of criminal responsibility. First, while most of us abhor punishment without blame, it is difficult to articulate the necessary conditions of blame. Like injustice and pornography, we know freedom from blame when we see it. ${ }^{140}$ The Court's inability to articulate universal principles of blame and fashion them into rules is evident in its current doctrine on various aspects of mens rea. ${ }^{141}$

A second difficulty that prevents the Court from creating a coherent doctrine of crimmal responsibility is that decisions in this area inevitably involve inoral judgments. To have the Supreme Court decide what states of mind, occurring in conjunction with whatever harms the legislature lad proscribed, are sufficiently immoral to justify a criminal sanction or sufficiently moral to excuse the conduct would raise grave questions about whose niorality the law should impose upon a pluralistic nation.

A final problem that prevents Supreme Court development of a theory of criminal responsibility is that any formulation of culpability that poses the issue of moral culpability as merely one of fact for the jury is inadequate. Even traditional doctrines of mens rea are inadequate indicia of moral culpability; many cominentators view inens rea "as simply a principle of voluntary action." 142 American juries should know today, as they did in the late eighteenth century, that the duty they have in criminal cases is not only to decide facts but also to decide the defendant's guilt in the moral as well as factual sense of that word. ${ }^{143}$

\section{IV}

\section{Mens ReA AND the Sixth Amendment}

\section{A. Advantages of a Sixth Amendment Analysis}

The requirement that a jury find mens rea before convicting a criminal defendant should function as an affirmative limit on government

139. See, e.g., Dubin, supra note 12, at $377-78$ (proposing to make proscription, conformity, and function principles necessary conditions for invoking criminal sanctions).

140. P. BRETT, supra note 13 , at 42.

141. See supra text accompanying notes 72-124.

142. Allen, supra note 60 , at 751 .

143. See supra notes $37-38$ and accompanying text. 
power. Such a requirement is not a question of policy or morality, of competing ideas which must vie for dominance in the usual fashion through the normal channels of representative government. The requirement instead divides power between the rulers and the ruled. This view of the culpability requirement addresses the Court's major objection to denying enforcement of strict liability crimes: the fear of usurping legislative power. From a functional perspective, the issue changes from Congress versus the Supreme Court to Government versus the People.

By legislating not only the acts prohibited but also the mental events that must accompany those acts for punishment to attach, the legislature asserts a power that previously vested in no branch of government, a power that, when the Constitution was written, vested directly in the people in their role as Jury. The Supreme Court has long enforced the structural separation of powers and assured that no branch of government oversteps the limited grant of power given it by the Constitution. ${ }^{144}$ Therefore, if the people, by serving as the ultimate arbiters of the blameworthiness of their fellow citizens, have the power under the Constitution to limit the power of government to punish criminal acts, if this power is implicit in the Constitution's command that all criminal trials be by Jury, ${ }^{145}$ then tlie Supreme Court has not only the power but the duty to deny the legislature the right to define blameworthiness in the criminal spliere.

Although the legislature cannot constitutionally define moral guilt and frame it as a "mere" fact question, it can require juries (and has for more than one hundred years) to find as a matter of fact that a defendant had a certain mental state when slie committed the crime charged. ${ }^{146} \mathrm{~A}$ legislative specification of a mental state as an element of a crime serves a function different from a jury finding of moral blame. ${ }^{147}$ First, legislative specification of a mental state may serve to identify the harm the legislature wishes to prevent. ${ }^{148}$ For example, part of the very harm of the crime of perjury is the intent with which the lie is told. The legislature has no interest in deterring mere mistakes in testimony. ${ }^{149}$ Second, specification of mental state may also determine what punishment the state will impose, a determmation traditionally made by the state. ${ }^{150}$

144. Marbury v. Madison, 5 U.S. (1 Cranch) 137 (1803); see also L. TRIBE, AmeriCAN CONSTITUTIONAL LAW $\S 3-2$ (1978).

145. U.S. CoNST, art. III, $\S 2$, cl. 3; id. amend. VI.; id. amend. IX ("The enumeration in the Constitution, of certain rights, shall not be construed to deny or disparage others retained by the people.").

146. P. BRETT, supra note 13 , at $71-72$.

147. See id. at 73-74.

148. See Dubin, supra note 12 , at 354.

149. See id. at 354-55.

150. For a concise history of sentencing, see S. Shane-DuBow, A. Brown, \& E. OlsEN, SENTENCING REFORM IN THE UNITED STATES: HistoRy, CONTENT, AND EFFECT 1-12 (1985). 
The Court's confusion about the different roles the term "mental state" plays in criminal law may have contributed to its reluctance to develop a theory of criminal responsibility and to strike down legislation inconsistent with that theory. Because the Court has framed the mens rea question in terms of which branch of government will define the mental element, it has failed to see that it can enforce the defendant's right not to be criminally punished if norally innocent without usurping the legislature's power to define crimes and set punishinents.

Focusing on the sixth ainendinent alleviates many of the analytic and practical difficulties of current mens rea jurisprudence. If the jury trial guaranteed under the Constitution and the sixth ainendment inpliedly mandates that jurors be the final arbiters of moral guilt, as demonstrated above, ${ }^{151}$ the Court need not decide which legislative forinulations of mental state are permissible. Likewise, the Court need not develop mental state formulations of its own. Its job changes from examining legislative intent to determining whether the defendant received a proper jury trial. The question on review would be: did the court instruct the jury in this case that whether or not the prosecution proved all elements of its case beyond a reasonable doubt, the jury must not convict if it believes the defendant was morally innocent of the crime charged? If the answer is no, the court would not strike down the law under which the defendant was charged; rather, it would reverse the conviction and grant a new trial.

Under this sixth amendment approach, legislators would retain the widest possible discretion to define proscribed harms. Furthermore, the Court would not perceive itself as substituting its morality for the morality of the legislature. Moral judgment would be, as the Framers intended, in the hands of the local community.

\section{B. Limits of Suggested Approach}

The proposed sixth amendment-based mens rea jurisprudence does not address two problenis: (1) it does not protect morally innocent defendants from conviction for petty crimes, and (2) it allows the legislature full discretion to fix punishment once a jury has answered the baseline question of whether a defendant is morally culpable for the charged offense, regardless of the magnitude of a defendant's blameworthiness.

\section{Petty Crimes}

The analysis proposed in this Comment, of course, would apply only

151. See supra text accompanying notes 2-36; see also P. BRETT, supra note 13, at 74 ("The jury's function in a criminal trial is not merely that of deciding the facts; it is that of deciding guilt."). 
in criminal prosecutions to which the right to trial by jury attaches. Despite the plain language of the Constitution, ${ }^{152}$ the Supreme Court has held that only serious offenses require jury trials, while the court can try petty offenses. ${ }^{153}$ Thus, a defendant has no right to a jury determination of moral blameworthiness in a trial for a petty crime.

In determining whether a particular offense is serious enough to require a jury trial, the Court looks both to the nature of the offense itself and to the inaximum potential sentence. ${ }^{154}$ The Court also has established a bright-line rule that a maximum potential sentence in excess of six inonths imprisonment is sufficiently severe to make the offense a "serious" one. ${ }^{155}$ State and lower federal courts are still grappling with the issue of when the nature of the offense renders it serious, ${ }^{156}$ looking to such factors as whether the offense was a crime at cominon law, whether it is malum in se or malum prohibitum, and whether it carries with it significant collateral consequences. ${ }^{157}$ Because these factors bear on the inoral opprobriuin with which the community views an offense, requiring a mens rea finding in all jury-determined cases may serve to ensure that strict criminal liability will be restricted to crimes for which "conviction does no grave dainage to an offender's reputation."158

\section{Degrees of Blameworthiness}

Under my suggested sixth ainendinent approach, a jury must decide that the defendant is morally culpable for the offense charged before convicting her. However, the jury would not decide whether the defendant is blameworthy enough to merit whatever punishinent the court eventually imposes.

For example, burglary in California is divided into two degrees. First degree burglary is burglary of a residence, while second degree bur-

152. The sixth amendment provides: "In all criminal prosecutions, the accused shall enjoy the right to a speedy and public trial, by an impartial jury of the State and district wherein the crime shall have been committed . . . ." U.S. CONST. amend. VI (emphasis added). Article III provides: "The Trial of all Crimes, except in Cases of Impeachment, shall be by Jury . . . " U.S. CoNST. art. III, $\S 2$, cl. 3 (emphasis added).

153. Duncan v. Louisiana, 39I U.S. 145, 159 (1968).

154. Baldwin v. New York, 399 U.S. 66, 69 n.6 (1970).

155. Id. Congress has defined a petty offense as "[a]ny misdemeanor, the penalty for which, as set forth in the provision defining the offense, does not exceed imprisonment for a period of six months or a fine of not more than $\$ 5,000$ for an individual and $\$ 10,000$ for a person other than an individual, or both." 18 U.S.C. $\$ 1$ (Supp. IV 1986). A legislative classification of an offense as petty, however, is not dispositive of the constitutional issue. See Landry v. Hoepfner, 818 F.2d 1169, 1176 (5th Cir. 1987) (driving while intoxicated, an offense classified by Louisiana statutory scheme as petty, held by court to be serious and thus to require jury trial).

156. Compare Landry, 818 F.2d at 1171-77 with id. at 1179-88 (Garwood, J., dissenting).

157. See Landry, 818 F.2d at 1174-75.

158. Morissette v. United States, 342 U.S. 246, 256 (1952). 
glary is burglary of any other building. ${ }^{159}$ First degree burglary carries a much stiffer penalty than does second degree burglary. ${ }^{160}$

A California court of appeal has determined that the legislature did not intend that the accused must know he was entering a residence to be convicted of first degree burglary. ${ }^{161}$ The court noted that ignorance of the residential character of the building entered did not negate the defendant's wrongful intent, ${ }^{162}$ and that " 'a mistake of fact relating only to the gravity of an offense will not shield a dehberate offender from the full consequences of the wrong actually committed." "163 Thus, ignorance that a building is a residence "provides no protection from the increased punishinent that is imposed for his actual conduct." 164 The court suggested that the legislature chose the greater penalty for residential burglary because of the greater danger to the commumity created by that crime, ${ }^{165}$ rather than because residential burglary implicates greater moral culpability. Under a sixtl amendinent mens rea analysis, this result would be permissible. A jury would decide only whether the defendant coinmitted the proscribed act and was morally wrong to do so; the legislature would determine what punishment fits the crinie.

A recent Supreine Court case suggests, however, that under the eiglith amendment, the Court miglit require, at least in capital cases, soine relationship between a defendant's moral culpability and the punishment imposed. In Tison v. Arizona ${ }^{166}$ the Court held that the eightl amendment does not prohibit the death penalty when a defendant acting with reckless indifference to huinan life takes a inajor role in a felony that results in murder. ${ }^{167}$ The Court noted, however, that the death penalty may be impermissible in the case of a defendant not slown to liave any culpable inental state. ${ }^{168}$ It left open the question whether those persons acting with a degree of culpability short of reckless indifference (e.g. negligence) miglit suffer capital punishment. Justice O'Connor's opinion for the Court, lowever, seems to imply that reckless indifference is a baseline culpability requirement for capital punisliment, given the historical importance of reserving that punisliment for "the most culpable and dangerous of murderers." 169

159. See Cal. Penal Code $\S 460$ (West 1970 \& Supp. 1988).

160. See Cal. Penal Code $\S 461$ (West 1970 \& Supp. 1988).

161. People v. Parker, 175 Cal. App. 3d 818, 223 Cal. Rptr. 284 (1985).

162. Id. at 822-23, 223 Cal. Rptr. at 287.

163. Id. at 823, 223 Cal. Rptr. at 287 (quoting People v. Lopez, 271 Cal. App. 2d 754, 760-61, 77 Cal. Rptr. 59, 64 (1969)).

164. Id. at 823,223 Cal. Rptr. at 287.

165. Id. at 823-24, 223 Cal. Rptr. at 287-88.

166. 107 S. Ct. 1676 (1987).

167. Id. at 1688 .

168. Id. at 1687.

169. Id. 
Tison thus may require that a defendant at least have demonstrated reckless indifference to human life before the state may kill her. It is unlikely, however, that the case will be of much benefit to a defendant not facing a death sentence because the holding was based partly on the principle that death is "unique in its severity and irrevocability"; therefore the state must consider the individual culpability of the defendant before imposing that sentence. ${ }^{170}$ In noncapital cases, by contrast, "the States generally have wide discretion in deciding how much retribution to exact in a given case." 171

\section{CONCLUSION}

The Supreme Court has recognized that the Framers considered jurors to be more than mere fact finders:

[T]he jury trial provisions in the Federal and State Constitutions reflect a fundamental decision about the exercise of official power-a reluctance to entrust plenary powers over the life and liberty of the citizen to one judge or to a group of judges. Fear of unchecked power, so typical of our State and Federal Governments in other respects, found expression in the criminal law in this insistence upon community participation in the determination of guilt or innocence. ${ }^{172}$

Both historical forces and resulting Supreme Court mens rea jurisprudence have eroded the importance of the jury's function as judge of moral culpability. Because of its deference to legislatures, the Court has permitted criminal punishment of defendants no jury has found morally blameworthy. This development has occurred despite universal recognition at the time the Constitution was adopted that there can be no finding of criminal guilt without a contemporaneous finding of moral guilt. Moreover, it has occurred despite near universal recognition of the same principle today.

By recognizing that the Constitution allocates the job of deciding moral guilt to the jury, the Court would protect a criminal defendant's absolute right to be free of the criminal sanction if she is without moral blame. Furthermore, it would leave the legislative branch free to perform its job of defining crimes. Under this system, no agent of the state would ever pass on an individual defendant's moral culpability. Moral blame would be assessed, as the framers intended, by a jury of one's peers.

Ann Hopkins*

170. Id. at 1683 (quoting Gregg v. Georgia, 428 U.S. 153, 187 (1976)).

171. Id. at 1683.

172. Duncan v. Louisiana, 391 U.S. 145, 156 (1967).

- B.A. 1979, Bennington College; J.D. 1987, Boalt Hall School of Law, University of California, Berkeley; Assistant Public Defender, Alameda County. 